\title{
KEDUDUKAN TAKLIK TALAK DALAM PERKAWINAN ISLAM DITINJAU DARI HUKUM PERJANJIAN
}

\author{
Syaefuddin Haris
}

PT. Toba Group, Jakarta

Email: haris.kanz@yahoo.com

\begin{abstract}
Taklik divorce is a divorce in the fall or hang it on a case specific reasons that have been agreed upon. Addendum agreement with the divorce has different agreements in general in terms of closing the possibility of both parties to dissolve the agreement referred to in Article 46 paragraph (3) KHI addendum stating that the divorce agreement is not a treaty that must be held at each marriage. But once they fall addendum divorce irrevocably. In line with the contents of the divorce sigheh addendum, the addendum divorce in Marriage Legislation Indonesia entered the marriage treaty article. Legal implications that can arise when a husband is breaking pledges addendum divorce, it can be categorized as an offense, and the offense can be used as an excuse by the wife filed a complaint for divorce to the court religion.
\end{abstract}

Key words: taklik separations, agreements, marriage

\begin{abstract}
Abstrak
Taklik talak adalah talak yang jatuhnya di gantungkan pada suatu perkara atau alasan-alasan tertentu yang telah disepakati. Perjanjian taklik talak mempunyai perbedaan dengan perjanjian pada umumnya dalam hal tertutupnya kemungkinan kedua belah pihak untuk membubarkan kesepakatan tersebut sebagaimana disebutkan dalam Pasal 46 ayat (3) KHI yang menyatakan bahwa perjanjian taklik talak bukan suatu perjanjian yang wajib diadakan pada setiap perkawinan. Akan tetapi sekali taklik talak sudah diperjanjikan tidak dapat dicabut kembali. Sejalan dengan isi sighat taklik talak tersebut, maka taklik talak dalam perundang-undangan Perkawinan Indonesia pun masuk pada pasal perjanjian perkawinan. Implikasi hukum yang dapat ditimbulkan adalah apabila suami melanggar ikrar taklik talak, maka dapat dikategorikan sebagai pelanggaran, dan pelanggaran tersebut dapat dijadikan alasan oleh istri untuk mengajukan tuntutan perceraian kepada pengadilan agama.
\end{abstract}

Kata kunci: taklik talak, perjanjian, perkawinan

\section{Latar Belakang}

Ikatan perkawinan merupakan unsur pokok dalam pembentukan keluarga yang harmonis dan penuh rasa cinta kasih, oleh karena itu dalam pelaksanaan perkawinan memerlukan norma hukum yang mengaturnya. Penerapan norma hukum dalam pelaksanaan perkawinan terutama diperlukan dalam rangka mengatur hak, kewajiban, dan tanggung jawab masingmasing anggota keluarga, guna membentuk rumah tangga yang bahagia dan sejahtera. 
Menurut Hukum Islam perkawinan (pernikahan) adalah suatu akad yaitu akad yang menghalalkan pergaulan (hubungan suami isteri) dan membatasi hak dan kewajiban serta tolong menolong antara lakilaki dan seorang perempuan yang dua-duanya bukan muhrim, artinya apabila seorang pria dan seorang perempuan bersepakat diantara mereka untuk membentuk suatu rumah tangga, maka hendaknya kedua calon suami isteri tersebut terlebih dahulu melakukan akad nikah. ${ }^{1}$

Menurut pandangan masyarakat, perkawinan merupakan tali ikatan yang melahirkan keluarga sebagai dasar kehidupan masyarakat dan negara. Guna mewujudkan kesejahteraan dan kebahagian masyarakat, perlu adanya landasan yang kokoh dan kuat sebagai titik tolak pada masyarakat yang adil dan makmur, hal ini dituangkan dalam suatu Undang-undang Perkawinan yang berlaku bagi semua warga negara di wilayah negara Kesatuan Republik Indonesia. ${ }^{2}$

Sebagai Negara Hukum Indonesia telah mengatur tentang perkawinan yang tertuang dalam Undang-undang Perkawinan dan telah dilengkapi dengan Peraturan Pemerintah Nomor 9 tahun 1975 yaitu tentang pelaksanaan Undang-undang Nomor 1 Tahun 1974 tentang Perkawinan, dan Intruksi Presiden Nomor 1 Tahun 1991 tentang Kompilasi Hukum Islam (KHI) dan peraturan-peraturan lainnya mengenai perkawinan.

Perkawinan mempunyai tujuan antara lain membentuk keluarga (rumah tangga) yang bahagia dan kekal berdasarkan Ketuhanan Yang Maha Esa sebagaimana dinyatakan dalam Pasal 1 Undang-undang Perkawinan. Dengan demikian, maka sebenarnya tidak perlu diragukan lagi, apakah sebenarnya yang ingin dicapai dalam perkawinan itu. Namun karena keluarga atau rumah tangga itu berasal dari dua individu yang berbeda, maka dari dua individu itu mungkin terdapat tujuan yang berbeda, untuk itu perlu penyatuan tujuan perkawinan demi tercapainya keluarga yang sakinah.

Keluarga merupakan keluarga bahagia bila dalam keluarga itu tidak terjadi kegoncangankegoncangan atau pertengkaran-pertengkaran, sehingga keluarga itu berjalan dengan baik tanpa goncangan-goncangan atau pertengkaran-pertengkaran yang berarti (free from quarelling). ${ }^{3}$

Tujuan perkawinan yang lain selain membentuk keluarga bahagia, juga bertujuan lain yaitu bersifat kekal. Di Dalam sebuah perkawinan perlu ditanamkan bahwa perkawinan itu berlangsung untuk waktu seumur hidup dan selama-lamanya kecuali dipisahkan karena kematian. Tujuan perkawinan menurut Islam adalah menuruti perintah Allah untuk memperoleh keturunan yang sah dalam masyarakat, dengan

1 Bakri A. Rahman dan Ahmad Sukardja, Hukum Perkawinan Menurut Hukum Islam, Undang-Undang Perkawinan dan Hukum Perdata/BW, Hidakarya Agung, Jakarta, 1981, hlm. 11.

2 Ibid., hlm. 12.

3 Cholil Mansyur, Sosiologi Masyarakat Kota dan Desa, Usaha Nasional, Surabaya, 1994, hlm. 16. 
mendirikan rumah tangga yang damai dan teratur. ${ }^{4}$ Hal ini senada dengan firman Allah dalam Al Qur'an Surat ar-Rum ayat 21 yang artinya: "Dan di antara tanda-tanda kekuasaan-Nya, Dia (Allah) menciptakan untukmu isteri-isteri dari jenismu sendiri, supaya kamu cenderung dan merasa tentram kepadanya, dan dijadikan-Nya di antara kamu rasa kasih sayang. Sesungguhnya pada yang demikian itu benar-benar terdapat tanda-tanda bagi kaum berfikir".

Fenomena di dalam masyarakat kadang berbicara lain, perkawinan yang diharapkan sakinah, mawadah, warohmah ternyata karena satu dan lain hal harus kandas di tengah jalan. Kondisi rumah tangga mengalami perselisihan, pertengkaran serta suami istri sudah tidak dapat lagi didamaikan maka Islam memberi solusi dengan perceraian atau talak. Perceraian atau talak merupakan obat terakhir untuk mengakhiri pertentangan dan pergolakan antara suami istri serta menjadi jalan keluar yang layak untuk keduanya. Kendati dibolehkan Allah membenci perceraian atau talak.

Pada Pasal 38 Undang-undang Perkawinan disebutkan bahwa perkawinan dapat putus karena tiga hal, yaitu karena kematian, karena perceraian dan atas putusan pengadilan. Tindak lanjut dari pengaturan ketentuan tersebut lebih rinci dijelaskan dalam Pasal 19 Peraturan Pemerintah Nomor 9 Tahun 1975 yang menjelaskan keadaan yang dapat dijadikan alasan perceraian diantaranya:
1. Salah satu pihak berbuat zina atau menjadi pemabuk, pemadat, penjudi, dan lain sebagainya yang sulit disembuhkan.

2. Salah satu pihak meninggalkan pihak lain selama 2 tahun berturut-turut tanpa izin pihak lain dan tanpa alasan yang sah atau karena hal lain di luar kemampuannya.

3. Salah satu pihak mendapat hukuman selama 5 tahun atau lebih berat setelah perkawinannya berlangsung

4. Salah satu pihak melakukan kekejaman atau penganiayaan berat yang membahayakan pihak lain.

5. Salah satu pihak mendapat cacat badan atau penyakit dengan akibat tidak dapat menjalankan kewajiban suami istri.

6. Antara suami istri terus menerus terjadi perselisihan dan pertengkaran dan tidak ada harapan untuk rukun lagi dalam rumah tangga.

Menurut Hukum Islam, seorang suami mempunai hak talak sedangkan istri tidak. Talak adalah hak suami, karena dialah yang berminat melangsungkan perkawinan, dialah yang berkewajiban memberi nafkah, dia pula yang wajib membayar mas kawin, mut'ah, serta nafkah dan iddah. Di samping itu lakilaki adalah orang yang lebih sabar terhadap sesuatu yang tidak disenangi oleh perempuan. Laki-laki tidak akan segera menjatuhkan talak apabila marah atau ada kesukaran yang menimpanya. Sebaliknya kaum wanita itu lebih cepat marah, kurang tabah sehingga ia cepat-cepat minta cerai hanya karena ada

4 Slamet Abidin dan Aminuddin, Fiqih Munakahat 1, Pustaka Setia, Bandung, 1999, hlm. 12-18. 
sebab yang sebenarnya sepele atau tidak masuk akal. Karena itulah kaum wanita tidak diberi hak untuk menjatuhkan talak. ${ }^{5}$

Meskipun istri tidak mempunyai hak talak, akan tetapi ia dapat mengajukan gugatan perceraian terhadap suaminya. Hal ini dengan tegas dinyatakan dalam Pasal 114 KHI, yang selengkapnya berbunyi "Putusnya perkawinan yang disebabkan karena perceraian dapat terjadi karena talak atau berdasarkan gugatan perceraian". Dengan adanya hak untuk mengajukan gugatan itu apabila seorang istri ingin bercerai dengan suaminya, tentu saja didasarkan pada alasanalasan yang dibenarkan oleh hukum, maka ia dapat mengajukan perceraian ke Pengadilan Agama. Dengan demikian, dalam hal perceraian, hak antara seorang suami dan istri adalah seimbang. ${ }^{6}$

Putusnya perkawinan karena perceraian, di Indonesia pada umumnya menggunakan lembaga taklik talak (cerai talak). Hal ini juga berdasarkan bunyi Pasal 116 huruf g Kompilasi Hukum Islam yang berbunyi Perceraian dapat terjadi karena alasan Suami melanggar taklik talak dan tidak sedikit pula yang putus karena putusan pengadilan, diantaranya ialah gugat cerai dengan alasan pelanggaran taklik talak. Lembaga taklik talak di Indonesia telah ada sejak zaman dahulu. Kenyataan yang ada sampai saat ini pun menunjukkan hampir setiap perkawinan di
Indonesia yang dilaksanakan menurut agama Islam selalu diikuti pengucapan sighat taklik oleh suami. Sekalipun sifatnya suka rela, namun di negara ini, membaca taklik talak seolah-olah menjadi kewajiban yang harus dilaksanakan oleh suami.

Berdasarkan Maklumat Kementerian Agama Nomor 3 Tahun 1953, Departemen Agama menganjurkan kepada pejabat daerah agar dalam pernikahan itu dibacakan taklik talak. Sighat taklik dirumuskan sedemikian rupa untuk melindungi istri dari sikap kesewenang-wenangan suami, jika istri tidak rela atas perlakuan suami maka istri dapat mengajukan gugatan perceraian berdasarkan terwujudnya syarat taklik talak yang disebutkan dalam sighat taklik.

Rumusan sighat taklik talak adalah rumusan yang ditetapkan berdasarkan Peraturan Menteri Agama Nomor 2 Tahun 1990, yang rumusan lengkapnya adalah sebagai berikut:

Sesudah akad nikah, saya ...... bin .... berjanji dengan sesungguh hati, bahwa saya akan menepati kewajiban saya sebagai seorang suami, dan akan saya pergauli istri saya bernama ... binti .... dengan baik (mu'asyarah bil-ma'ruf) menurut ajaran syari'at Islam.

Selanjutnya saya mengucapkan sighat taklik atas istri saya itu sebagai berikut: Sewaktu-waktu saya:

(1) meninggalkan istri saya tersebut dua tahun berturut-turut.

\footnotetext{
5 Abdul Rachmad Budiono, Peradilan Agama dan Hukum Islam di Indonesia, Bayumedia Publishing, Malang, 2003, hlm. 64.

$6 \quad$ Ibid., hlm. 64-65.
} 
(2) Atau saya tidak memberi nafkah wajib kepadanya tiga bulan lamanya,

(3) Atau saya menyakiti badan/jasmani istri saya itu,

(4) Atau saya membiarkan (tidak memperdulikan) istri saya itu enam bulan lamanya,

kemudian istri saya tidak ridho dan mengadukan halnya kepada Pengadilan Agama atau petugas yang diberi hak mengurus pengaduan itu, dan pengaduan dibenarkan serta diterima oleh pengadilan atau petugas tersebut, dan istri saya itu membayar uang sebesar Rp.10.000,- (sepuluh ribu rupiah) sebagai iwadh (pengganti) kepada saya, maka jatuhlah talak saya satu kepadanya.

Kepada pengadilan atau petugas tersebut tadi saya kuasakan untuk menerima uang iwad (pengganti) itu dan kemudian menyerahkannya kepada Badan Kesejahteraan Masjid (BKM) Pusat untuk keperluan ibadah sosial.

Berdasarkan rumusan tersebut ada 10 unsur-unsur pokok sighat taklik talak yakni:

1. Suami meninggalkan istri, atau;

2. Suami tidak memberi nafkah kepada istri, atau;

3. Suami menyakiti istri, atau;

4. Suami membiarkan tidak (memperdulikan) istri;

5. Istri tidak rela;

6. Istri mengadu ke pengadilan;

7. Pengaduan istri diterima oleh Pengadilan;

8. Istri membayar uang iwad;

9. Jatuhnya talak satu suami kepada istri;

10. Uang iwad oleh suami diterimakan kepada
Pengadilan untuk selanjutnya diserahkan kepada pihak ketiga untuk kepentingan ibadah sosial.

Berdasarkan Undang-undang Nomor 1 Tahun 1974 tentang Perkawinan tidak ditemukan pasal yang secara khusus menyebutkan serta mengatur tentang taklik talak dalam kapasitasnya baik sebagai perjanjian perkawinan maupun sebagai alasan perceraian. Pasal 29 Undang-undang Nomor 1 Tahun 1974 ini hanya menyebutkan dibolehkannya bagi kedua mempelai untuk mengadakan perjanjian tertulis sebelum melangsungkan perkawinan. Dalam penjelasannya pada Pasal 29 Undang-undang Nomor 1 Tahun 1974 ditekankan bahwa perjanjian perkawinan yang dimaksud tidak termasuk taklik talak di dalamnya. Adapun bunyi Pasal 29 Undang-undang Nomor 1 Tahun 1974 secara lengkap adalah sebagai berikut:

(1) Pada waktu sebelum perkawinan dilangsungkan kedua pihak atas persetujuan bersama dapat mengadakan perjanjian tertulis yang disahkan oleh pegawai pencatat perkawinan. Setelah mana isinya berlaku juga terhadap pihak ketiga sepanjang pihak ketiga tersangkut.

(2) Perjanjian tersebut tidak dapat disahkan bilamana melanggar batas-batas hukum, agama dan kesusilaan

(3) Perjanjian tersebut berlaku sejak perkawinan dilangsungkan.

(4) Selama perkawinan berlangsung perjanjian tersebut tidak dapat dirubah, 
kecuali bila dari kedua belah pihak ada persetujuan untuk merubah dan perubahan tidak merugikan pihak ketiga.

Eksistensi taklik talak ternyata banyak melahirkan kontoversi, baik di kalangan fuqaha maupun para pengamat Hukum Islam. Permasalahan ini perlu dan relevan untuk dibahas agar penerapannya benar-benar sesuai dengan peraturan perundang-undangan dan benar-benar dapat memenuhi serta memberikan kepastian hukum bagi pencari keadilan.

Berdasarkan latar belakang tersebut di atas, maka pokok permasalahan yang akan dibahas dalam penelitian ini adalah:

1. Apakah taklik talak dalam suatu perkawinan Islam dapat dikategorikan sebagai perjanjian?

2. Apaimplikasihukumterhadap pelanggaran taklik talak bagi suatu perkawinan?

Penelitian ini menggunakan jenis penelitian hukum normatif berupa penelitian kepustakaan yang menggunakan 3 bahan hukum yaitu bahan hukum primer, bahan hukum sekunder dan bahan hukum tersier. Penelitian hukum ini menitikberatkan pada studi kepustakaan yang berarti akan lebih banyak menelaah dan mengkaji aturan-aturan hukum yang ada dan berlaku. Penelitian hukum normatifmerupakan suatu proses untuk menemukan aturan hukum, prinsip-prinsip hukum maupun doktrin-doktrin hukum guna menjawab isu hukum yang dihadapi sehingga diperoleh argumentasi, teori atau konsep baru sebagai preskripsi dalam menyelesaikan masalah. $^{7}$

Cara pendekatan (approach) yang digunakan dalam suatu penelitian hukum normatif akan memungkinkan seorang peneliti untuk memanfaatkan hasil-hasil temuan ilmu hukum empiris dan ilmu-ilmu lainnya untuk kepentingan dan analisis serta ekspalanasi hukum tanpa menguban karakter ilmu hukum sebagai ilmu normatif. ${ }^{8}$ Dalam penelitian ini ada 2 (dua) metode pendekatan yang digunakan, yaitu pendekatan perundangundangan (statute approach) dan pendekatan konseptual(conceptualapproach). Pendekatan perundang-undangan (statute approach) yaitu penelitian terhadap produk-produk hukum. Pendekatan konseptual (conceptual approach) merupakan suatu pendekatan yang digunakan untuk memperoleh kejelasan dan pembenaran ilmiah berdasarkan konsep-konsep hukum yang bersumber dari prinsip-prinsip hukum. ${ }^{9}$

Cara pengolahan bahan hukum dilakukan secara induktif yaitu menarik kesimpulan dari suatu permasalahan konkret yang bersifat khusus kepada permasalahan abtsrak yang bersifat umum. Selanjutnya bahan hukum yang ada dianalisis secara deskrptif yang diawali dengan mengelompokkan bahan hukum yang sama menurut sub aspek dan selanjutnya melakukan interpretasi untuk

7 Peter Mahmud Marzuki, Penelitian Hukum, Kencana, Jakarta, 2005, hlm. 35.

8 Johnny Ibrahim, Teori dan Metodologi Penelitian Hukum Normatif, Bayumedia Publishing, Malang, 2010, hlm. 300 .

9 Peter Mahmud Marzuki, Op. Cit., hlm. 138. 
memberikan makna terhadap tiap subaspek dan hubungannya satu sama lain. Kemudian setelah itu dilakukan analisis keseluruhan aspek untuk memahami makna hubungan antara aspek yang satu dengan lainnya dan dengan keseluruhan aspek yang menjadi pokok permasalahan penelitian yang dilakukan secara induktif sehingga memberikan gambaran hasil secara utuh. ${ }^{10}$

\section{Pembahasan}

a. Kedudukan Taklik Talak Dalam Perkawinan Islam Ditinjau Dari Hukum Perjanjian

Pasal 1 huruf e Kompilasi Hukum Islam dinyatakan perjanjian perkawinan adalah perjanjian yang diucapkan calon mempelai pria setelah akad nikah yang dicantumkan dalam Akta Nikah berupa janji talak yang digantungkan kepada suatu keadaan tertentu yang mungkin terjadidi masa yang akan datang. Rumusan definisi perjanjian perkawinan yang disebutkan dalam Kompilasi Hukum Islam lebih bersifat universal-konsepsional yang berarti tidak mencampur-adukkan antara kebijakan yang sifatnya temporal dengan konsep dasar perjanjian perkawinan yang sifatnya permanen dan universal.

Perjanjian Perkawinan dalam KHI terdapat dalam BAB VII yang di dalamnya mengatur taklik talak sebagaimana yang terdapat dalam Pasal 45 dan Pasal 46 yang berbunyi: "Kedua calon mempelai dapat mengadakan perjanjian perkawinan dalam bentuk: (1) Taklik Talak. (2) Perjanjian lain yang tidak bertentangan dengan Hukum Islam. Adapun mengenai penjelasannya adalah kata perjanjian berasal dari kata janji yang berarti perkataan yang menyatakan kesediaan dan kesanggupan untuk berbuat. Janji juga dapat diartikan persetujuan antara dua pihak (masing-masing menyatakan kesediaan dan kesanggupan untuk berbuat sesuatu). Dan perjanjian bisa juga diartikan sebagai persetujuan tertulis atau dengan lisan yang dibuat oleh dua pihak atau lebih, masingmasing berjanji menaati apa yang tersebut dalam persetujuan itu. Perjanjian taklik talak adalah perjanjian yang diucapkan oleh suami setelah akad nikah yang dicantumkan dalam akta nikah berupa talak yang digantungkan kepada suatu keadaan tertentu yang mungkin terjadi di masa yang akan datang.

Sedangkan dalam Pasal 46 KHI berbunyi:

(1) Isi taklik talak tidak boleh bertentangan dengan Hukum Islam.

(2) Apabila keadaan yang disyaratkan dalam taklik talak betul-betul terjadi di kemudian, tidak dengan sendirinya talak jatuh. Supaya talak sungguh-sungguh jatuh, istri harus mengajukan persoalannya ke pengadilan agama.

(3) Perjanjian taklik talak bukan suatu perjanjian yang wajib diadakan pada setiap perkawinan, akan tetapi sekali taklik talak sudah diperjanjikan tidak dapat dicabut kembali. 
Berdasarkan pada ketentuan di atas, maka dapat dikatakan bahwa:

a. Isi taklik talak sudah ditentukan oleh Menteri Agama dan diterbitkan oleh Departemen Agama, karena yang melakukan perjanjian taklik talak ini adalah orang Islam saja, maka isi perjanjian taklik talak tersebut tidak boleh bertentangan dengan Hukum Islam.

b. Apabila suami melanggar perjanjian taklik talak tersebut, maka istri harus mengajukannnya ke pengadilan agama. Karena perceraian di Indonesia terjadi apabila dilakukan di hadapan para hakim dalam sidang di pengadilan agama. Hal ini bisa juga dikatakan sebagai talak yang dijatuhkan oleh hakim. Menurut Imam Maliki, Syafi'i, dan Ahmad bin Hanbali memperbolehkan seorang wanita menuntut talak dari hakim karena adanya sebab-sebab berikut ini: ${ }^{11}$

(1) Tidak diberi nafkah. Ketiga ulama madzhab tersebut sepakat bahwa apabila seorang suami terbukti tidak mampu memberi nafkah pokok kepada istrinya, maka istrinya itu tidak boleh mengajukan tuntutan cerai. Tetapi bila ketidakmampuannya itu tidak terbukti dan suami tidak mau memberi nafkah, maka Imam Syafi'i mengatakan bahwa suami istri itu tidak boleh diceraikan. Sementara itu Imam Maliki dan Imam Ahmad bin Hanbal mengatakan suami istri itu dapat diceraikan, lantaran tidak adanya nafkah bagi istri sama artinya dengan ketidakmampuan suami memberi nafkah.

(2) Istri merasa terancam baik berupa ucapan atau perbuatan suami.

(3) Terancam kehidupan istri karena suami tidak berada di tempat. Menurut Imam Maliki dan Ahmad bin Hanbal, sekalipun si suami meninggalkan nafkah yang cukup untuk selama masa ketidakhadirannya. Bagi Imam Ahmad, jarak minimal sang istri boleh mengajukan gugatan cerai adalah enam bulan sejak kepergian suaminya, dan tiga tahun menurut Maliki (menurut pendapatnya yang lain satu tahun).

(4) Istri terancam kehidupannya karena suami berada dalam penjara.

c. Taklik talak tidak wajib hukumnya, akan tetapi sekali taklik talak diucapkan maka tidak dapat dicabut kembali, dalam hal ini taklik talak sangat mengikat bagi yang mengadakan perjanjian taklik talak ini.

Dari ketentuan perjanjian perkawinan yang termuat dalam Kompilasi Hukum Islam Pasal 45 ayat (2) bahwa perjanjian lain yang tidak bertentangan dengan Hukum Islam terdapat kaitannya dengan perjanjian yang ada dalam Pasal 1320 KUHPerdata mengemukakan bahwa undang-undang telah menentukan 4 
(empat) persyaratan yang harus dipenuhi agar suatu perikatan atau perjanjian dianggap sah yaitu:

a. Kesepakatan mereka yang mengikat diri.

b. Kecakapan untuk membuat suatu perikatan.

c. Suatu hal tertentu.

d. Suatu sebab yang halal.

Dengan demikian, perjanjian perkawinan yang diatur dalam Kompilasi Hukum Islam, walau dengan teks yang berbeda mempunyai unsur-unsur yang sama dengan perjanjian dalam KUHPerdata. Namun demikian, dalam perjanjian taklik talak mempunyai perbedaan dengan perjanjian pada umumnya dalam hal tertutupnya kemungkinan kedua belah pihak untuk membubarkan kesepakatan tersebut sebagaimana disebutkan dalam Pasal 46 ayat (3) KHI yang menyatakan bahwa perjanjian taklik talak bukan suatu perjanjian yang wajib diadakan pada setiap perkawinan. akan tetapi sekali taklik talak sudah diperjanjikan tidak dapat dicabut kembali.

Untuk mengukur apakah taklik talak sebuah perjanjian atau bukan, kita harus melihat Pasal 1320 KUH Perdata yang memuat syarat sahnya perjanjian yaitu (1) Sepakat meraka yang mengikatkan dirinya, (2) Cakap mereka yang mengikatkan diri, (3) Suatu hal tertentu, dan (4) Suatu sebab atau kausa yang halal. Syarat-syarat sahnya perjanjian sebagaimana tersebut di atas dapat dikategorikan menjadi dua, yaitu kategori syarat subjektif dan kategori syarat objektif. Syarat subjektif, yaitu syarat sepakat mereka yang mengikatkan diri dan syarat kecakapan untuk membuat perjanjian. Apabila syarat subjektif tidak dapat dipenuhi maka perjanjian dapat dibatalkan (Vernieitigbaar). Syarat objektif, yaitu syarat suatu hal tertentu dan syarat suatu sebab yang halal. Apabila dalam perjanjian syarat objektif tidak dipenuhi, maka perjanjian adalah batal demi hukum. ${ }^{12}$

Adanya kata sepakat bagi mereka yang mengikatkan diri adalah adanya kemauan yang bebas sebagai syarat pertama untuk suatu perjanjian yang sah. Di dalam taklik talak, suami istri telah sepakat tanpa paksaan untuk menandatangani persetujuan bersama yang tertuang dalam konsep taklik talak itu, karena taklik taklak bukan sebuah keharusan bagi berlangsungnya sebuah perkawinan.

Cakap maksudnya adalah kedua belah pihak harus cakap menurut hukum untuk bertindak sendiri. Didalamhukumperkawinan, seseorang boleh dapat melangsungkan perkawinan apabila berumur 19 tahun lak-laki dan 16 tahun bagi perempuan, artinya suami istri tersebut sudah dewasa dan cakap hukum untuk melakukan perbuatan hukum.

Suatu hal tertentu maksudnya yang diperjanjikan dalam suatu perjanjian haruslah suatu hal atau suatu barang yang cukup jelas atau tertentu. Di dalam taklik talak ini, yang diperjanjikan sudah jelas yang tertuang dari isi taklik talak tersebut. 
Suatu sebab atau kausa yang halal artinya perjanjian itu tidak dilarang atau tidak bertentangan dengan peraturan perundangundangan. Karena keberadaan taklik talak untuk melindungi si istri dari perbuatan suami, maka keberadaan taklik talak tidak bertentangan dengan peraturan perundangundangan. Berdasarkan Pasal 1320 KUH Perdata tersebut, taklik talak adalah sebuah perjanjian.

Menurut Az-Zaqra, perjanjian (akad) dalam terminologi fikih adalah ikatan secara hukum yang dilakukan oleh dua atau beberapa pihak yang sama-sama berkeinginan untuk mengikat diri. ${ }^{13}$

Ali Al-Sayis memberikan komentar lebih lanjut bahwa perjanjian dalam Islam itu bukan hanya perjanjian yang bersifat partai, tetapi juga termasuk perjanjian sepihak, bahkan juga termasuk janji kepada Tuhan. Berkaitan dengan ruang lingkup perjanjian ini Ibn Araby mengemukakan pendapatnya, ada 5 (lima) hal yang termasuk dalam kategori perjanjian, yakni;

a. Perjanjian secara umum.

b. Sumpah.

c. Kewajiban yang telah dibebankan Allah kepada hambanya.

d. Akad Nikah, perkongsian (syirkah), jual beli, sumpah dan janji kepada Allah.

e. Perikatan atas dasar saling mempercayai. ${ }^{14}$
Sayid Sabiq menguraikan dalam Fikih Sunnah bahwa perjanjian perkawinan yang disebut sebagai taklik talak ada dua macam bentuk:

a. Taklik yang dimaksud sebagai janji, karena mengandung pengertian melakukan peker-jaan atau meninggalkan suatu perbuatan atau menguatkan suatu kabar. Dan taklik talak seperti ini disebut dengan ta'liq qasami.

b. Taklik yang dimaksudkan untuk menjatuhkan talak bila telah terpenuhi syarat ta'liq. Taklik seperti ini disebut dengan ta'liq syarti. ${ }^{15}$

Dari kedua bentuk taklik talak di atas dapat dibedakan dengan kata-kata yang diucapkan oleh suami. Pada ta'liq qasamy, suami bersumpah untuk dirinya sendiri. Sedangkan pada taklik talak suami mengajukan syarat dengan maksud jika syarat tersebut ada maka jatuhlah talak suami pada isterinya.

Adapun konsep taklik talak dan perjanjian perkawinan dalam Perundang-undangan Perkawinan negara-negara muslim, di luar Indonesia dapat digambarkan secara singkat sebagai berikut:

a. Malaysia

Perundang-undangan Keluarga Muslim Malaysia, dimana disebutkan juga adanya kemungkinan membuat taklik talak dan perjanjian perkawinan.

13 Abdul Aziz Dahlan (Ed), Ensiklopedi Hukum Islam Jilid I, PT. Ichtiar Baru van Hoeve, Jakarta, 2000, hlm. 63.

14 Abu Zakariya Muhammad ibn Abdullah Ibn Araby, Ahkam al-Qu'an Juz II, Dar al- Ma'rifah, Beriut, hlm. 524-525. 
Kemungkinan ini disebutkan misalnya pada Pasal 22 Undang-undang Selangor (Islamic Family Law of State of Selangor, Enactment 2003). Adapun alasan yang dapat dimasukkan dalam taklik talak ada tiga. Pertama, suami meninggalkan isteri selama 4 bulan, disengaja atau tidak. Kedua, suami tidak memberikan nafkah sementara isteri patuh kepada suami. Ketiga, suami melakukan sesuatu yang membuat isteri cacat/sakit. Sekedar tambahan, hukum mengucapkan sighat taklik talak di Malaysia tidak wajib, namun tetap berlaku meskipun tidak diucapkan. ${ }^{16}$

b. Singapura

Dalam Perundang-undangan Keluarga Singapore, kemungkinan taklik talak dicantumkan dalam Formulir (form) Nomor 4. Dalam formulir ini diberikan kemungkinan kepada isteri mengajukan perpisahan dengan empat alasan. Pertama, suami meninggalkan isteri selama 4 bulan, disengaja atau tidak. Kedua, suami tidak memberikan nafkah sementara isteri patuh kepada suami. Ketiga, suami melakukan sesuatu yang membuat isteri rusak/sakit badan dan hartanya, dan menyebabkan kehilangan kehormatan. Alasan ini berlaku dengan syarat isteri mengadukan ke pengadilan, ketika pengaduan terbukti, maka jatuh talak satu. ${ }^{17}$

c. Maroko

Perundang-undangan

Perkawinan Maroko, masalah taklik talak dicantumkan pada Pasal 31 the Code of Personal Status 1957-1958 (Qanûn alAkhwâl al-Syakhsîyah). Isi dari pasal ini bahwa isteri boleh menetapkan dalam akad nikah bahwa suaminya tidak akan poligami. Jika suaminya berpoligami, isteri berhak mengajukan perceraian. Isi dari pasal ini secara khusus hanya menyinggung poligami sebagai alasan kemungkinan terjadi perceraian, yang diajukan isteri karena keberatan. ${ }^{18}$

d. Siriah

Dalam Qanûn al-Akhwâl al- Syaksîyah Syria Nomor 59 Tahun 1953, masalah taklik talak dicantumkan dalam Pasal 14. Pada ayat (i) disebutkan, manakala dalam satu akad nikah dibuat taklik talak yang bertentangan dengan syariat, maka takliknya tidak sah, tetapi akad nikahnya sendiri tetap sah. Ayat (ii) dalam satu akad nikah yang menetapkan taklik talak untuk kepentingan isteri, maka ketetapan berlaku, dengan syarat tidak bertentangan dengan syari'at, tidak merugikan pihak ketiga, dan tidak menghilangkan hak suami. Ayat (iii)

15 A. Fuad Said, Perceraian Menurut Hukum Islam, Pustaka al-Husna, Jakarta, 1994, hlm. 41-42.

16 Khoiruddin Nasution, Menjamin Hak Perempuan dengan Taklik Talak dan Perjanjian Perkawinan, Jurnal UNISIA, Vol. XXXI No. 70, Desember 2008, hlm. 339.

17 Ibid., hlm. 340. 
dimana isteri menetapkan taklik dalam akad nikah, yang menghilangkan hak pihak ketiga atau hak isteri, meskipun berlaku bagi suami, tetapi dapat menjadi dasar bagi isteri untuk minta cerai apabila dilanggar suami. Dalam pasal ini tidak disebutkan dan tidak dibatasi alasan yang boleh dicantumkan dalam taklik talak. Dengan aturan ini malah memungkinkan mencantumkan cakupan alasan yang lebih luas. Menurut beberapa penelitian, alasan yang paling umum dicantumkan dalam taklik talak Siriah adalah suami tidak boleh pergi ke luar negeri mencari pekerjaan. Alasan ini didorong oleh kenyataan banyaknya kasus suami yang pergi mencari pekerjaan di luar negeri, namun kemudian tidak pulang lagi dan menikah lagi di negara tempat tinggalnya. Fenomena ini menjadi momok bagi wanita dan orang tua di Siriah. ${ }^{19}$

e. Yaman Utara

Undang-undang Yaman Utara Tahun 1978 (Qanûn al-Usrah), masalah taklik talak dicantumkan dalam Pasal 4, bahwa satu perkawinan yang ada taklik (perjanjian perkawinan) yang sah dan berlaku bagi pihak-pihak, maka perkawinannya adalah sah dan perjanjian pun berlaku. Kemudian ditambahkan, perjanjian tidak boleh dirubah kecuali atas persetujuan bersama. $^{20}$ f. Lebanon

Lebanon Law on Family Rights 19171962, yang dicantumkan dalam Pasal 38. pasal ini berisi, ketika seorang wanita menetapkan dengan suaminya bahwa suami tidak poligami, maka tindakan poligami suami dapat menjadi alasan isteri untuk minta talak, baik isteri pertama maupun isteri kedua. ${ }^{21}$

g. Somalia

Taklik talak dalam Undang-undang Perkawinan Somalia (Family Code of Somalia Nomor 23 Tahun 1975) dicantumkan dalam Pasal 43. Pasal ini memuat sejumlah alasan yang memungkinan pasangan suami dan isteri untuk berpisah. Alasan-alasan dimaksud ada tujuh yaitu:

1. salah satu pasangan mengidap penyakit yang menghalangi mereka mengadakan hubungan seksual, dan penyakit dimaksud dibuktikan oleh hasil pemeriksaan (keterangan) dokter,

2. tidak diketahui keberadaanya selama empat tahun,

3. fakir miskin yang mengakibatkan suami tidak dapat mencukup nafkah keluarga,

4. kedua suami dan isteri miskin, dan mereka tidak dapat menyelesaikannya selama enam bulan, 
5. terjadi perselisihan serius antara pasangan suami dan isteri, dan juru damai (arbitrador) tidak mampu mendamaikan,

6. salah satu pasangan tidak dapat melakukan hubungan seksual, dan

7. isteri berhak mintai cerai disebabkan suami poligami yang diijinkan oleh hakim, sesuai dengan Pasal 13.

Isi Pasal 13 Hukum Perkawinan Somalia adalah kemungkinan poligami bagi suami dan harus mendapatkan ijin dari pengadilan dengan sejumlah alasan. Alasan-alasan dimaksud adalah:

1. isteri mandul yang dibuktikan dengan surat keterangan dokter,

2. isteri mengidap penyakit berkepanjangan (tidak dapat disembuhkan) dan mengakibatkan tidak dapat melakukan hubungan seksual, yang dibuktikan oleh dokter,

3. isteri dipenjara lebih dari satu tahun,

4. isteri meninggalkan rumah tanpa alasan yang jelas, dan

5. karena ada kepentingan sosial, yang ijin untuk ini dikeluarkan oleh menteri kehakiman dan menteri agama.

Dengan demikian, dalam perundangundangan Somalia, meskipun ada kemungkinan poligami, dengan ijin dan dengan syarat-syarat tertentu, tetapi poligami suami ini dapat menjadi alasan isteri minta cerai. ${ }^{22}$
Sejalan dengan isi sighat taklik tersebut, maka taklik talak dalam Perundang-undangan Perkawinan Indonesia pun masuk pada pasal perjanjian perkawinan, yang tercantum pada bab V, Pasal 29 Undang-undang Nomor 1 Tahun 1974 tentang Perkawinan. Demikian juga perjanjian perkawinan dicantumkan dalam Kompilasi Hukum Islam Indonesia (KHI), yang diatur dalam bab VII: Perjanjian Perkawinan (Pasal 45 s/d 52).

\section{b. Implikasi Hukum Terhadap} Pelanggaran Taklik Talak Bagi Suatu Perkawinan

\section{b.1. Pelaksanaan Sighat Taklik Talak Dalam Perkawinan}

Suatu ijab dan qobul perkawinan sering kali diadakan suatu ikrar yang dibaca oleh mempelai pria setelah ijab qobul selesai dilaksanakan. Petugas dari KUA biasanya menyuruh membaca ikrar yang dinamakan taklik talak, yaitu suatu perjanjian yang diucapkan calon mempelai pria setelah akad nikah yang dicantumkan dalam akta nikah berupa janji talak yang digantungkan kepada suatu keadaan tertentu yang mungkin terjadi di masa yang akan datang. Dari isi taklik talak dapat diketahui bahwasanya apabila suami nantinya melanggar isi taklik talak, maka ini bisa dijadikan sebagai alasan istri untuk menggugat cerai suaminya. Perjanjian semacam ini menurut Undang-undang Nomor 1 Tahun 1974 tentang Perkawinan 
dan menurut Kompilasi Hukum Islam, boleh dilaksanakan. Isi perjanjian tersebut pada dasarnya tidak bertentangan dengan hukum positif dan Hukum Islam. Sekilas kita melihat bahwa ikrar taklik talak ini sebagai bentuk kesungguhan mempelai pria kepada mempelai wanita bahwa ia akan selalu mencintai istrinya dan berjanji akan melaksanakan kewajibannya sebagai seorang suami dengan baik. Hal ini juga memberikan perlindungan hukum bagi wanita karena mendapat jaminan dari suaminya.

Suatu perkawinan menurut hukum positif di Indonesia yang juga diilhami dari Hukum Islam pada dasarnya bertujuan untuk membentuk keluarga yang bahagia dan kekal berdasarkan Ketuhanan Yang Maha Esa. Hendaknya kita sadar bahwa perkawinan bukan bertujuan hanya untuk sesaat saja. Di dalam sebuah perkawinan terkandung hak dan kewajiban masing-masing, baik itu suami maupun istri. Suami sebagai kepala keluarga mempunyai kewajiban yang tidak ringan, diantaranya ia harus menyayangi istri dan mampu memberikan nafkah lahir maupun batin. Nah, ikrar taklik talak pada dasarnya memberi jaminan atas terpenuhinya kewajiban suami ini. Memang ini untuk melindungi wanita, tapi apakah harus dengan cara demikian.

Secara normatif, seorang laki-laki yang menikah juga telah berjanji kepada Allah SWT untuk memperlakukan istrinya dengan baik, menjaga kemuliaan serta tidak menganiayanya. Apabila dirinci kewajiban suami atas istrinya terdiri dari:

a. Nafkah. Setiap suami wajib memenuhi nafkah bagi keluarganya sesuai dengan kesanggupannya. Namun dilarang pula seorang suami memberikan nafkah secara berlebihan karena mempunyai dampak negatif. Memberi nafkah kepada keluarganya merupakan tugas suci bagi seorang suami. Jadi memberi nafkah bagi keluarga merupakan prioritas pertama bagi seorang suami.

b. Tempat Tinggal. Ulama menafsirkan bahwa seorang suami mempunyai kewajiban memberikan papan bagi istrinya secara layak dan sesuai dengan kemampuannya. Di dalam rumah itulah seorang istri mampu sepenuhnya menempatkan diri sebagai pemimpin rumah tangga.

Pengucapan shigat taklik talak selepas akad nikah masih dipersoalkan oleh masyarakat Indonesia yang akhirnya dengan Keputusan MUI pada tanggal 23 Rabiul Akhir 1417 H., bertepatan dengan 7 September 1996, mengucapkan shigat taklik talak tidak diperlukan lagi. Adapun alasan keputusan ini dapat digambarkan sebagai berikut:

a. bahwa materi shigat taklik talak pada dasarnya telah dipenuhi dan tercantum dalam Undang-undang Nomor 1 Tahun 1974 tentang Perkawinan dan Undangundang Nomor 7 Tahun 1989 tentang Peradilan Agama sebagaimana telah diganti dengan Undang-undang Nomor 3 Tahun 2006 tentang Peradilan Agama. 
b. menurut Kompilasi Hukum Islam (KHI), perjajian taklik talak bukan merupakan keharusan dalam setiap perkawinan (KHI Pasal 46 Ayat (3)).

c. bahwa konteks mengucapkan shigat taklik talak menurut sejarahnya adalah untuk melindungi hak-hak wanita, dimana waktu itu taklik talak belum ada dalam peraturan perundang-undangan perkawinan. Karena itu, setelah adanya aturan tentang itu dalam peraturan perundang-undangan perkawinan, maka mengucapkan shigatnya tidak diperlukan lagi.

Di dalam fatwa yang ditandatangani oleh Ketua MUI: Hasan Basri, Sekretaris MUI: H. A. Nazri Adlani, dan Ketua Komisi Fatwa K.H. Ibrahim Hosen ini, disebutkan bahwa "Pengucapan sighat ta'liq talaq, yang menurut sejarahnya untuk melindungi hak-hak wanita (isteri) yang ketika itu belum ada peraturan perundang-undangan tentang hal tersebut, sekarang ini pengucapan sighat ta'liq talaq tidak diperlukan lagi. Untuk pembinaan ke arah pembentukan keluarga bahagia sudah di bentuk BP4 dari tingkat pusat sampai dengan tingkat kecamatan. ${ }^{23}$

Menurut KHI, perjanjian taklik talak bukan merupakan keharusan dalam setiap perkawinan. Hal ini kita dapat kita baca di dalam Pasal 46 Ayat (3), "Perjanjian taklik talak bukan suatu perjanjian yang wajib diadakan pada setiap perkawinan, akan tetapi

22 Ibid., hlm. 340-341. sekali taklik talak sudah diperjanjikan tidak dapat dicabut kembali." Dengan demikian maka menurut KHI tersebut jelas menyebutkan bahwa perjanjian taklik talak bukanlah suatu keharusan bagi setiap muslim.

Adapun taklik talak yang berlaku di Indonesia telah diatur sedemikian rupa dan untuk memudahkan pelaksanaannya telah disediakan teksnya yang berisikan syaratsyarat tertulis dan PPN hanya menawarkan kepada mempelai apakah dibacakan taklik talak atau tidak. Bila dibacakan maka di buku nikah akan dibubuhi tanda tangan suami sebagai bukti bahwa suami telah mengucapkan janji dihadapan istri. Bila suami tidak bersedia membaca taklik talak, maka teks taklik talak yang tersedia dicoret petugas sebagai tanda suami tidak membaca taklik talak. Karena pembacaan taklik talak ini hanya anjuran, maka suami pun berhak untuk tidak membacakannya di hadapan mempelai istri.

\section{b.2. Pelanggaran Taklik Talak Sebagai Alasan Perceraian}

Pembahasan mengenai taklik talak sebagai alasan perceraian telah dibahas para ulama fiqih dalam berbagai kitab fiqih. Dalam pembahasan mengenai hal ini mereka ikhtilaf. Ada yang membolehkan dan ada pula yang menolaknya, ada yang pro dan ada pula yang kontra. Perbedaan tersebut sampai sekarang mewarnai perkembangan Hukum Islam. 
Di antara yang membolehkan pun terdapat dua pendapat. Ada yang membolehkan secara mutlak dan ada yang membolehkan dengan syarat-syarat tertentu. Perbedaan faham di antara mereka yang membolehkan, pada dasarnya terletak pada bentuk sifat dan sighat taklik talak yang bersangkutan. Yang membolehkan secara mutlak, mereka membolehkan semua bentuk sighat taklik, baik yang bersifat syarthi maupun qasami, yang bersifat umum maupun yang dikaitkan dengan sesuatu. Sedang yang membolehkan ialah sighat taklik yang bersifat syarthi, dan sesuai dengan maksud tujuan hukum syar' $i .{ }^{24}$

Ulama berbeda pendapat tentang jatuh atau tidaknya talak dengan dua formulasi di atas. Jumhur Ulama berpendapat bahwa dua bentuk taklik yang dikaitkan dengan talak/ janji, apabila yang ditaklikkan terjadi maka talaknya jatuh. Sedangkan Ibn Hazm dan Ibn Oayyim al-Jauziyah berpendapat bahwa taklik yang di dalamnya terkandung maksud sumpah (qasam) tidak berakibat jatuhnya talak, akan tetapi wajib membayar kifarat sumpah dan taklik yang di dalamnya terkandung syarat yang dimaksudkan untuk menjatuhkan talak ketika terjadinya sesuatu yang disyaratkan, maka talak tersebut jatuh. ${ }^{25}$

Muhammad Yusuf Musa mengemukakan pendapatnya bahwa taklik talak yang diucapkan suami dapat membawa konsekuensi jatuhnya talak suami kepada isteri apabila dipenuhi syarat sebagai berikut:

a. Bahwa yang ditaklikkan itu adalah sesuatu yang belum ada ketika taklik diucapkan tetapi dimungkinkan terjadi pada masa yang akan datang.

b. Pada saat taklik talak diucapkan obyek taklik (isteri) sudah menjadi isteri sah bagi pengucap taklik.

c. Pada saat taklik talak diucapkan suami isteri berada dalam majelis tersebut. ${ }^{26}$

Fakta yuridis mengenai alasan perceraian sebagaimana yang tersebut dalam Pasal 39 Ayat (2) UU Perkawinan beserta penjelasannya, maupun dalam Pasal 19 Peraturan Pemerintah Nomor 9 Tahun 1975, tidak disinggung mengenai taklik talak sebagai alasan perceraian. Pembuat undang-undang menganggap bahwa perceraian berdasarkan penjelasan Pasal 39 Ayat (2) Undang-undang Perkawinan jo. Pasal 19 Peraturan Pemerintah Nomor 9 Tahun 1975 telah cukup memadai, sesuai dengan jiwa undang-undang tersebut yang antara lain menganut asas mempersukar terjadinya perceraian. Sehingga tidak perlu lagi ditambah atau diperluas.

M. Yahya Harahap dalam karyanya Tinjauan Masalah Perceraian di Indonesia, juga mengatakan demikian. Dinyatakan bahwa Undang-undang Perkawinan tidak menutup perceraian. Pada saat yang bersamaan undang-

23 Anonim, Sighat Taklik Talak,...Mestikah di Ucapkan, http://jilbab.or.id/archives/78-sighat-takliktalakmestikah-di-ucapkan/, diakses pada tanggal 27 Maret 2013.

24 Mahmoud Syaltut, Perbandingan Mazhab Dalam Masalah Fiqh, Terjemahan Ismuha, Bulan Bintang, Jakarta, 1978, hlm. 218-219.

25 Zakiyuddin Sya'ban, al-Ahkam al-Syar'iyah li af-Ahwal al-Syakhsiyah, al-Nahdah al-Arabiyah, Mesir, 1967, hlm. 442. 
undang juga tidak membuka lebar-lebar pintu perceraian. Oleh karena itu jumlah perceraian harus dibatasi. Apa yang diatur dalam aturan perundang-undangan dianggap cukup memadai, mensejajari kebutuhan masyarakat. Apalagi jika dilihat dari keluwesan Pasal 19 huruf f Peraturan Pemerintah Nomor 9 Tahun 1975, dan dikaitkan dengan perluasan alasan "melalaikan kewajiban" sebagaimana yang diatur dalam Pasal 34 Ayat (3) Undangundang Perkawinan. Alasan perceraian yang kita miliki lebih dari cukup. Tidak perlu ditambah, dan memang alasan perceraian telah ditetapkan oleh undang-undang secara limitatif. Dilihat dari itu maka tidak ada alasan yang dapat dipergunakan. ${ }^{27}$

Namun bila dicermati dari fakta yang ada saat ini, nampak jelas bahwa perkara cerai gugat dengan alasan taklik talak yang diterima oleh Pengadilan Agama mencapai jumlah yang tidak sedikit, mencapai puluhan ribu setiap tahunnya.

Mengenai sikap Pengadilan Agama yang tampaknya telah membenarkan alasan perceraian di luar undang-undang dapat dirumuskan beberapa hal:

a. taklik talak dari segi esensinya sebagai perjanjian yang digantungkan kepada syarat dengan tujuan utamanya melindungi isteri dari kemudharatan karena tindakan sewenang-wenang suami, mempunyai landasan hukum yang kuat, yaitu dalildalil dari kitab suci Alquran dan Hadis. b. taklik talak sebagai alasan perceraian telah melembaga dalam Hukum Islam sejak lama, sejak masa sahabat. Sebagian besar ulama sepakat tentang sahnya dan sampai sekarang diamalkan oleh kaum muslimin di berbagai penjuru dunia, khususnya di Malaysia dan Indonesia.

c. substansi taklik talak yang telah ditetapkan oleh Menteri Agama RI, dipandang telah cukup memadai, dipandang dari asas Hukum Islam ataupun jiwa UU Perkawinan.

d. di Indonesia lembaga taklik talak secara yuridis formal telah berlaku sejak zaman penjajahan Belanda, berdasarkan Staatblaad 1882 Nomor 152 sampai sekarang setelah merdeka menjelang diundangkannya Undang-undang Perkawinan bahkan sampai menjelang diundangkannya Undang-undang Nomor 7 Tahun 1989 sebagaimana telah diganti dengan Undang-undang Nomor 3 Tahun 2006. Sekalipun Staatblad 1882 Nomor 152 yang memberi landasan yuridis berlakunya hukum taklik talak telah dicabut dengan Undang-undang Nomor 7 Tahun 1989 pada saat sekarang ini dengan diberlakukannya Kompilasi Hukum Islam melalui Instruksi Presiden Nomor 1 Tahun 1991 yang antara lain mengatur juga mengenai taklik talak maka taklik talak dapat dikategorikan sebagai hukum tertulis. 
Dalam praktik di Pengadilan Agama baik ia sebagai perjanjian atau pun alasan perceraian, maka hakim secara tegas mempertimbangkannya dalam putusannya. Hendaknya hakim mempertajam upaya dalam mengkonstatir, mengkualifisir maupun mengkonstituir perkaranya, sehingga kecenderungan selama ini untuk menggiring atau mengarahkan perkara cerai gugat menjadi perkara taklik talak dapat dikurangi.

Berdasarkan hal-hal tersebut di atas, kiranya ketentuan-ketentuan mengenai hukum acara dapat dilaksanakan dengan benar, dan ketentuan sebagaimana dikehendaki oleh Pasal 62 ayat (1) Undang-undang Nomor 7 Tahun 1989, yakni: Segala Penetapan dan Putusan Pengadilan, setelah memuat alasanalasan atau dasar-dasarnya, juga harus memuat pasal-pasal tertentu dari peraturanperaturan yang bersangkutan, dapat terpenuhi. Atas dasar ini pula bahwa taklik talak sebagai alasan perceraian relevan dan dapat dibenarkan menurut hukum. ${ }^{28}$ Karena Pasal 116 huruf g Bab VI dalam Kompilasi Hukum Islam dikatakan bahwa alasan perceraian adalah suami melanggar taklik talak.

Untuk memperkuat argumentasi taklik talak sebagai salah satu alasan untuk mengajukan tuntutan perceraian, Pengadilan Agama Solok dalam putusannya nomor Nomor: 13/Pdt.G/2012/PA Slk, dalam amar putusan, mengabulkan gugatan penggugat sebagai berikut:
1. Menyatakan bahwa Tergugat yang telah dipanggil secara resmi dan patut untuk datang menghadap di persidangan, tidak hadir;

2. Mengabulkan gugatan Penggugat dengan verstek;

3. Menyatakan syarat sighat taklik talak telah terpenuhi;

4. Menjatuhkan talak satu khul'i Tergugat (TERGUGAT) terhadap Penggugat (PENGGUGAT) dengan iwadh sebesar Rp.10.000,-(sepuluh ribu rupiah);

5. Memerintahkan kepada Panitera Pengadilan Agama Solok untuk mengirimkan salinan putusan ini yang telah berkekuatan hukum tetap/BHT kepada PPN/KUAKABUPATEN SOLOK dan PPN/KUA Jambi, untuk dicatat dalam daftar yang disediakan untuk itu;

6. Membebankan kepada Penggugat untuk membayar semua biaya yang timbul dalam perkara ini sebesar Rp. 301.000,(tiga ratus satu ribu rupiah);

Jauh sebelumnya pada tahun 2010, Pengadilan Agama Sibolga juga telah memutus bahwa taklik talak sebagai alasan perceraian, dalam putusannnya Nomor: 11/ Pdt.G/2010/PA.SBG, yang menatakan dalam amar putusan, bahwa:

1. Mengabulkan gugatan Penggugat;

2. Menyatakan syarat taklik talak telah terpenuhi;

3. Menyatakan jatuh talak satu khul'i 
Tergugat atas diri Penggugat dengan $i w a d h$

Rp 10.000,- (Sepuluh Ribu Rupiah);

4. Menghukum Penggugat untuk membayar biaya perkara ini sebesar Rp 144.000,(Seratus Empat Ribu Rupiah);

Pengadilan Agama Painan dalam putusannya Nomor: 21/Pdt.G/2011/PA.Pn. juga telah mengabulkan perceraian dengan dasar taklik talak sebagai alasannya, dalam amar putusan, disebutkan bahwa:

a. Menyatakan Tergugat yang telah dipanggil secara resmi dan patut untuk menghadap di persidangan tidak hadir;

b. Mengabulkan gugatan Penggugat dengan verstek;

c. Menyatakan syarat taklik talak telah terpenuhi;

d. Menetapkan jatuh talak satu khul'i Tergugat (TERGUGAT) terhadap Penggugat (PENGGUGAT) dengan iwadh Rp.10.000,- (Sepuluh Ribu Rupiah);

e. Memerintahkan Panitera Pengadilan Agama Painan untuk mengirimkan salinan putusan ini setelah berkekuatan hukum tetap kepada Pegawai Pencatat Nikah yang wilayahnya meliputi tempat tinggal Penggugat dan Tergugat serta kepada Pegawai Pencatat Nikah di tempat dilangsungkannya perkawinan Penggugat dan Tergugat untuk dicatat dalam daftar yang disediakan untuk itu;

f. Menghukum kepada Penggugat untuk membayar biaya perkara yang hingga kini dirancang sebesar Rp. 441.000,- (Empat

Ratus Empat Puluh Satu Ribu Rupiah).

Berdasarkan beberapa contoh putusan pengadilan di atas, taklik talak sebagai salah satu alasan untuk mengajukan tuntutan perceraian sudah diterapkan oleh hakim dalam menjatuhkan putusan. Dengan begitu, taklik talak sebagai salah satu alasan untuk mengajukan tuntutan perceraian sudah mendapat legitimasi hukum di Indonesia.

Dalam sistem hukum dunia, kompetensi perceraian sepenuhnya berada di tangan hakim. Pengadilan adalah satu-satunya forum yang dapat memenuhi permohonan cerai dan mengesahkan pembubaran mahligai perkawinan. Walaupun dalam Hukum Islam diketahui bahwa hakim sama sekali tidak mempunyai hak menjatuhkan talak terhadap istri dalam kondisi apapun. Islam tidak mengekang wanita, tetapi memberi kesempatan untuk menuntut talak di hadapan hakim seandainya ia merasakan penderitaan yang sangat berat dan tidak bisa hidup dalam naungan suami. Ia boleh meminta cerai atas dasar penderitaan ini dan hakim harus membuktikan dan menyelidiki perkaranya. ${ }^{29}$

Perceraian adalah hak pria, asalkan ia berlaku secara wajar terhadap istrinya. Perilaku yang wajar dari seorang pria terhadap isterinya ialah bahwa apabila ia berkehendak untuk hidup bersama isterinya, maka ia harus mengurusinya dengan sepatutnya, menghormati hak-hak isterinya, dan berlaku

29 Ibrahim Muhammad al-Jamal, Fiqh al-Mar'ah al-Muslimah (Fiqh Muslimah), Terjemahan Zaid Hussein al-Hamid, Pustaka Amani, Jakarta, 1995, hlm. 311. 
kasih sayang terhadapnya. Apabila tidak ada jalan baginya untuk meneruskan kehidupan bersama isterinya itu maka ia harus secara sopan dan ramah menceraikannya.

Kenyataan di lapangan terlihat banyaknya perceraian yang disebabkan kelalaian suami terhadap isteri dalam hal pengurusan, pemberian nafkah, dan penghargaan terhadap wanita. ${ }^{30}$ Dalam hal inilah tampak akan fungsi taklik talak yang mengikat pertanggungjawaban suami terhadap isterinya. Dari satu sisi suami akan lebih konsisten dan bertanggungjawab terhadap kelangsungan rumah tangga dan di sisi lain isteri akan lebih dihargai. Pelanggaran suami terhadap hal-hal yang termaktub dalam sighat taklik talak sudah merupakan alasan bagi istri untuk mengajukan keberatan dan menuntut dijatuhkannya talak. Walau masih terdapat beberapa pendapat yang kontradiktif terhadap keberadaan taklik saat ini, namun pengaruhnya terhadap penghargaan terhadap wanita dalam rumah tangga lebih besar.

Menurut Abdul Karim Amrullah, lembaga taklik talak dapat menolong wanita dari perbuatan kesewenang-wenangan lakilaki. Sebagaimana dahulu banyak terjadi di daerah Minangkabau, banyak perempuan yang terkatung-katung, tidak pernah bergaul dan tidak pernah diberi nafkah oleh suami, tetapi tidak pula diceraikan. Apabila mereka mengadu ke Pengadilan, mereka justru disalahkan karena sulitnya Hakim Agama mengabulkan gugatan perceraian dari mereka, padahal mereka benar-benar ditelantarkan oleh suaminya, kemudian banyak diantara mereka yang murtad, dengan sendirinya putuslah nikah dengan suaminya. Oleh karena itu pada tahun 1916, untuk membebaskan perempuan dari laki-laki yang tidak bertanggungjawab, atas usul beliau di daerah Minangkabau diberlakukan taklik talak. ${ }^{31}$

Mahmoud Syaltout dalam buku Perbandingan Mazhab menjelaskan bahwa para ahli Hukum Islam berpendapat bahwa perjanjian taklik talak adalah jalan terbaik dalam melindungi kaum wanita dari perbuatan tidak baik dari pihak suami. Sekiranya seorang suami telah mengadakan perjanjian taklik talak, ketika akad nikah dilaksanakan dan bentuk perjanjian itu telah disepakati bersama, maka perjanjian taklik talak itu dianggap sah untuk semua bentuk taklik. Apabila suami melanggar perjanjian yang telah disepakati itu maka isteri dapat meminta cerai kepada hakim yang telah ditunjuk oleh pihak yang berwenang. ${ }^{32}$ Untuk itulah maka sesuai dan menurut kemaslahatan bagi suami maupun isteri, eksistensi taklik talak sangatlah penting. ${ }^{33}$ Perceraian yang wajar dan normal

\footnotetext{
30 Victor Situmorang, Kedudukan Wanita di Mata Hukum, PT Bina Aksara, Jakarta, 1988, hlm. 10.

31 Hamka, Tafsir al-Azhar Juz V, Panji Masyarakat, Jakarta, 1981, hlm. 71.

32 Daniel S. Lev, Islamic Court in Indonesia, Peradilan Agama Islam di Indonesia, Terjemahan H. Zaini Ahmad Noeh, PT. Intermasa, Jakarta, 1986, hlm. 4.

33 Murtadha Muthahhari, The Rights of Women in Islam, Terjemahan M. Hashem, Penerbit Pustaka, Bandung, 1997, hlm. 197.
} 
ibarat suatu kelahiran yang normal, yang berlangsung sendirinya secara normal, tetapi perceraian dari seorang suami yang tidak mau melaksanakan kewajibannya dan tidak mau pula menceraikan isterinya ibarat suatu kelahiran yang tidak alami dan tidak normal, dimana diperlukan seorang dokter atau ahli bedah (hakim).

Sesuai dengan pernyataan ikrar dari suami, apabila suami melanggar ikrarnya tersebut, maka pelanggaran tersebut dapat dijadikan alasan oleh istri untuk mengajukan tuntutan perceraian kepada pengadilan agama. Hakim akan memberikan keputusan perceraian apabila ternyata gugatan pihak istri beralasan dan terbukti. Apabila memperhatikan bentuk taklik talak di atas dapat dipahami bahwa maksud yang dikandungnya amat baik dan positif kepastian hukumnya, yaitu melindungi istri dari kesewenang-wenangan suami dalam memenuhi kewajibannya yang merupakan hak-hak istri yang harus diterimanya. Sesuai dengan ajaran Islam, seorang suami mempunyai kewajiban memelihara istrinya dengan sebaik-baiknya, berarti hak istri adalah memperoleh pemeliharaan sebaik baiknya dari suaminya.

Keberadaan taklik talak apabila ditinjau dari hukum perjanjian, merupakan sebuah perjanjian yang apabila dilanggar menimbulkan konsekuensi yuridis yaitu suami telah melakukan perbuatan ingkar janji atau wanprestasi, sehingga menurut penulis si istri dapat menggugat si suami ke pengadilan negeri untuk menuntut hak-haknya yang telah dilanggar oleh suami tersebut sesuai bunyi dari taklik talak yang ada. Hal ini berdasarkan argumentasi bahwa taklik talak itu adalah sebuah perjanjian yang telah disepakati bersama baik oleh suami ataupun oleh istri.

\section{Simpulan}

Perjanjian perkawinan diatur dalam Kompilasi Hukum Islam, walau dengan teks yang berbeda mempunyai unsurunsur yang sama dengan perjanjian dalam KUHPerdata adalah merupakan perjanjian pada umumnya. Namun demikian, dalam perjanjian taklik talak mempunyai perbedaan dengan perjanjian pada umumnya dalam hal tertutupnya kemungkinan kedua belah pihak untuk membubarkan kesepakatan tersebut sebagaimana disebutkan dalam Pasal 46 ayat (3) KHI yang menyatakan bahwa perjanjian taklik talak bukan suatu perjanjian yang wajib diadakan pada setiap perkawinan. Akan tetapi sekali taklik talak sudah diperjanjikan tidak dapat dicabut kembali.

Implikasi hukum yang dapat ditimbulkan adalah apabila suami melanggar ikrar taklik talak tersebut, maka itu dapat dikategorikan sebagai pelanggaran, dan pelanggaran tersebut dapat dijadikan alasan oleh istri untuk mengajukan tuntutan perceraian kepada pengadilan agama. Apabila memperhatikan bentuk taklik talak di atas dapat dipahami bahwa maksud yang dikandungnya amat baik dan positif kepastian hukumnya, yaitu melindungi istri dari kesewenang-wenangan suami dalam memenuhi kewajibannya 
yang merupakan hak-hak istri yang harus diterimanya.

Saran/rekomendasi yang dapat diberikan adalah bahwa keberadaan taklik talak merupakan salah satu bentuk jaminan perlindungan hukum bagi istri dari tindakan kesewenang-wenangan suami. Oleh karena itu maka perlu payung hukum yang kuat dan jelas. Pengaturan taklik talak diharapkan tidak hanya diatur dalam Kompilasi Hukum Islam dan Peraturan Menteri Agama saja, melainkan harus juga diatur secara tegas dalam Undangundang Perkawinan yang menyatakan bahwa taklik talak merupakan perjanjian dalam perkawinan.
Mengingat implikasi hukum yang terjadi sangat besar dalam pelanggaran terhadap taklik talak, maka diharapkan kepada para suami benar-benar memahami isi dari taklik talak dan tidak hanya sekedar diucapkan demi formalitas dalam rangkaian acara ijab qabul suatu perkawinan. Begitu juga kepada para wali atau pegawai pencatat perkawinan atau pembantu pegawai pencatat perkawinan (penghulu) harus lebih memberikan pemahaman yang jelas saat penyampaian nasehat atau tausyiah setelah pembacaan sighat taklik.

\section{DAFTAR PUSTAKA}

\section{Buku}

A. Fuad Said, 1994, Perceraian Menurut Hukum Islam, Pustaka al-Husna, Jakarta.

Abdul Aziz Dahlan (Ed), 2000, Ensiklopedi

Hukum Islam Jilid I, PT. Ichtiar Baru van Hoeve, Jakarta.

Abdul Rachmad Budiono, 2003, Peradilan

Agama dan Hukum Islam di

Indonesia, Bayumedia Publishing, Malang.

Abu Zakariya Muhammad ibn Abdullah Ibn Araby, 2000, Ahkam al-Qu'an Juz II, Dar al- Ma'rifah, Beriut.

Bahder Johan Nasution, 2008, Metode

Penelitian Ilmu Hukum, Mandar Maju, Bandung.
Bakri A. Rahman dan Ahmad Sukardja, 1981, Hukum Perkawinan Menurut Hukum Islam, Undang-undang Perkawinan dan Hukum Perdata/ BW, Hidakarya Agung, Jakarta.

Cholil Mansyur, 1994, Sosiologi Masyarakat Kota dan Desa, Usaha Nasional, Surabaya.

Daniel S. Lev, 1986, Islamic Court in Indonesia, Peradilan Agama Islam di Indonesia, Terjemahan $H$. Zaini Ahmad Noeh, PT. Intermasa, Jakarta.

Hamka, 1981, Tafsir al-Azhar Juz V, Panji Masyarakat, Jakarta.

Ibrahim Muhammad al-Jamal, 1995, Fiqh al-Mar'ah al-Muslimah (Fiqh 
Muslimah), Terjemahan Zaid Hussein

al-Hamid, Pustaka Amani, Jakarta.

Johnny Ibrahim, 2010, Teori dan Metodologi

Penelitian Hukum Normatif,

Bayumedia Publishing, Malang.

M. Yahya harahap, 1989, Tinjauan Masalah

Perceraian di Indonesia, FH-UI, Jakarta.

Mahmoud Syaltut, 1978, Perbandingan

Mazhab Dalam Masalah Fiqh,

Terjemahan Ismuha, Bulan Bintang,

Jakarta.

Mohd. Idris Ramulyo, 1996, Hukum Islam

Perkawinan (Suatu Analisis Dari

Undang-undang No.1 Tahun 1974

dan Kompilasi Hukum Islam), Bumi

Aksara, Jakarta.

Muhammad Jawad Mughniyah, 2001,

al-fiqh ala al-Madzahib al-khamsah,

Terjemahann Masykur A.B., Afif

Muhammad dan Idrus Al-Kaff, Fiqih

Lima Madzhab, Lentera, Jakarta, .

Murtadha Muthahhari, 1997, The Rights

of Women in Islam, Terjemahan M.

Hashem, Penerbit Pustaka, Bandung.

Peter Mahmud Marzuki, 2005, Penelitian

Hukum, Kencana, Jakarta.

Purwahid Patrik, 1999, Dasar-Dasar Hukum

Perikatan, Mandar Maju, Bandung.

Slamet Abidin dan Aminuddin, 1999, Fiqih

Munakahat 1, Pustaka Setia, Bandung.

Victor Situmorang, 1988, Kedudukan

Wanita di Mata Hukum, PT Bina

Aksara, Jakarta.

Zakiyuddin Sya'ban, 1967, al-Ahkam

al-Syar'iyah li af-Ahwal

al-Syakhsiyah, al-Nahdah al-Arabiyah, Mesir.

\section{Jurnal}

Khoiruddin Nasution, 2008, Menjamin Hak Perempuan dengan Taklik Talak dan Perjanjian Perkawinan, Jurnal UNISIA, Vol. XXXI No. 70.

Artikel Internet

Anonim, Sighat Taklik Talak,... Mestikah di Ucapkan, http://jilbab. or.id/archives/78-sighat-takliktalakmestikah-di-ucapkan/.

\section{Peraturan Perundang-undangan}

Kitab Undang-undang Hukum Perdata.

Undang-undang Nomor 1 Tahun 1974 tentang Perkawinan.

Undang-undang Nomor 7 Tahun 1989 tentang Peradilan Agama.

Undang-undang Nomor 3 Tahun 2006 tentang Perubahan Atas Undangundang Nomor 7 Tahun 1989 tentang Peradilan Agama.

Peraturan Menteri Agama Nomor 2 Tahun 1990 tentang Kewajiban Pegawai Pencatat Nikah.

Peraturan Pemerintah Nomor 9 tahun 1975 tentang Pelaksanaan Undangundang Nomor 1 Tahun 1974 tentang Perkawinan.

Intruksi Presiden Nomor 1 Tahun 1991 tentang Kompilasi Hukum Islam (KHI).

Putusan Pengadilan Agama Solok Nomor: 13/ Pdt.G/2012/PA Slk. 
Maklumat Kementerian Agama Nomor 3 Qanûn al-Akhwâl al- Syaksîyah Syria Nomor Tahun 1953. 59 Tahun 1953.

Islamic Family Law of State of Selangor, Undang-undang Yaman Utara Tahun 1978 Enactment 2003. (Qanûn al-Usrah).

The Code of Personal Status 1957-1958 Lebanon Law on Family Rights 1917-1962.

(Qanûn al- Akhwâl al-Syakhsîyah). $\quad$ Family Code of Somalia Nomor 23 Tahun 1975. 